University of Navarra

\title{
THE INTELLECTUAL EVOLUTION OF STRATEGIC MANAGEMENT AND ITS RELATIONSHIP WITH ETHICS AND SOCIAL RESPONSIBILITY
}

Domènec Melé

Manuel Guillén 


\title{
THE INTELLECTUAL EVOLUTION OF STRATEGIC MANAGEMENT AND ITS RELATIONSHIP WITH ETHICS AND SOCIAL RESPONSIBILITY
}

\author{
Domènec Melé*
}

Manuel Guillén**

\section{Abstract}

The main purpose of this paper is to present an overview of the historical development of strategic management through a critical review of the most relevant theoretical proposals, and to consider its links to ethics and corporate social responsibility. From the very beginning of strategic management thought, attempts have been made to fuse ethical aspects, such as the values of senior management or social values or social expectations, to strategic management. More recently, the stakeholder view of the firm has permitted the introduction of ethical theories into strategic management, and the resource-based view of the firm has led to the consideration of competences, including moral virtues. Here it is argued that in spite of some advances, the integration of ethics into strategic management is not yet entirely satisfactory. Thus it is suggested that new directions are necessary to focus the integration of ethics and strategic management.

\footnotetext{
* Professor, Business Ethics, Chair Economics and Ethics, IESE

** Senior Lecturer in Srategic Management, University of Valencia
}

Keywords: Strategic Management, Integrating Ethics in Management, Business Ethics, Corporate Social Responsibility. 


\section{THE INTELLECTUAL EVOLUTION OF STRATEGIC MANAGEMENT AND ITS RELATIONSHIP WITH ETHICS AND SOCIAL RESPONSIBILITY}

\section{Introduction}

Recent studies on strategic management history include those which assess its evolution (e.g., Herrmann, 2005) and changes in its intellectual structure (Ramos-Rodríguez and Ruiz-Navarro, 2004). However, little attention has been paid to the relationship between ethics or social responsibility and strategic management. This, together with the relevance of the historical evolution of such a relationship, leads us to undertake the present study, the main purpose of which is to plot the explicit or implicit link between ethics or corporate social responsibility (CSR) and strategic management in the most influential schools of thought on strategic management. We also try to show that although there have been advances in integrating ethics and/or CSR into strategic management, such integrations have never been entirely satisfactory. Table I schemes an abridged history of strategic management thought. 


\section{Table I}

Abridged History of Strategic Management

\begin{tabular}{|c|c|c|c|c|c|}
\hline Period & 1960's & 1970's & 1980's & 1990's & 2000 \\
\hline Label & $\begin{array}{c}\text { Definition of } \\
\text { Strategy }\end{array}$ & $\begin{array}{c}\text { Conceptualizing } \\
\text { Strategic } \\
\text { Management }\end{array}$ & $\begin{array}{c}\text { Industrial } \\
\text { Organization } \\
\text { Economics View } \\
\text { of Strategy }\end{array}$ & $\begin{array}{l}\text { Resource-Based } \\
\text { View of Strategy }\end{array}$ & $\begin{array}{c}\text { New paradigm for } \\
\text { Strategic } \\
\text { Management }\end{array}$ \\
\hline $\begin{array}{l}\text { Some } \\
\text { leading } \\
\text { authors }\end{array}$ & $\begin{array}{l}\text { Chandler (1962) } \\
\text { Ansoff (1965) } \\
\text { Learned et al. } \\
\quad(1965) \\
\text { Andrews (1971) }\end{array}$ & $\begin{array}{c}\text { Rumelt (1974) } \\
\text { Mintzberg (1978) } \\
\text { Ansoff (1979) }\end{array}$ & $\begin{array}{l}\text { Porter (1980) } \\
\text { Porter (1986) }\end{array}$ & $\begin{array}{c}\text { Bartlett (1979) and } \\
\text { Ghoshal (1986) } \\
\text { Wernerfelt (1984) } \\
\text { Barney (1991) } \\
\text { Prahalad and } \\
\text { Hamel (1990) }\end{array}$ & $\begin{array}{c}\text { Nonaka (1991) } \\
\text { Hammel (2000) } \\
\text { Pfeffer and Sutton } \\
\text { (2000) }\end{array}$ \\
\hline $\begin{array}{c}\text { Dominant } \\
\text { themes }\end{array}$ & $\begin{array}{l}\text { Corporate strategy, } \\
\text { planning and } \\
\text { growth }\end{array}$ & $\begin{array}{c}\text { Strategic } \\
\text { management } \\
\text { content and } \\
\text { process }\end{array}$ & $\begin{array}{l}\text { Competitive } \\
\text { advantage } \\
\text { development }\end{array}$ & $\begin{array}{c}\text { Resources and } \\
\text { capabilities } \\
\text { development }\end{array}$ & $\begin{array}{l}\text { Learning, } \\
\text { Knowledge and } \\
\text { Innovation }\end{array}$ \\
\hline Rationale & $\begin{array}{l}\text { Strategy as a rule } \\
\text { for making } \\
\text { decisions }\end{array}$ & $\begin{array}{l}\text { Evaluation and } \\
\text { implementation of } \\
\text { critical aspects of } \\
\text { formulated } \\
\text { strategy }\end{array}$ & $\begin{array}{l}\text { Five forces analysis } \\
\text { of the industry } \\
\text { attractiveness to } \\
\text { develop competitive } \\
\text { advantage through } \\
\text { generic strategies }\end{array}$ & $\begin{array}{l}\text { Valuable, rare and } \\
\text { costly to imitate } \\
\text { resources without } \\
\text { close substitutes } \\
\text { can be sources of } \\
\text { sustained } \\
\text { competitive } \\
\text { advantage }\end{array}$ & $\begin{array}{l}\text { Dynamic strategic } \\
\text { model by which } \\
\text { firms obtain } \\
\text { valuable } \\
\text { information, create } \\
\text { knowledge and } \\
\text { accumulate } \\
\text { intangible } \\
\text { capabilities in a } \\
\text { process of learning }\end{array}$ \\
\hline $\begin{array}{c}\text { Strategic } \\
\text { concepts, } \\
\text { tools \& } \\
\text { techniques }\end{array}$ & $\begin{array}{c}\text { SWOT; Experience } \\
\text { Curve; Growth } \\
\text { Share Matrix }\end{array}$ & Value Chain & $\begin{array}{l}5 \text { forces model } \\
\text { Strategic choice }\end{array}$ & $\begin{array}{c}\text { Core Competence } \\
\text { Value System; } \\
\text { VRIO; Game } \\
\text { Theory }\end{array}$ & $\begin{array}{l}\text { New integrated } \\
\text { Information } \\
\text { Technology } \\
\text { Systems }\end{array}$ \\
\hline
\end{tabular}

\section{Including Personal Values and Social Responsibility within Strategy in the 1960s}

During the 1950s, academics and practitioners paid little attention to the practical concepts of strategy developed during World War II in the military arena. In this post-war period, given the stability of the markets and increases in demand, most companies in the U.S. and Europe were thinking primarily about efficient production systems. Later, by the 1960s, large companies moved from an emphasis on operations, budgeting and control areas to an emphasis on planning aspects. The growing complexity and dynamism of the environment and the need for solutions to this situation from the firm's top managers demanded future planning and a global view. As a result, most business schools by that time required "corporate policy" as the "capstone" course at the end of every business curriculum. Top executives were concerned with the general direction and long-term policy of their enterprises. Business policy professors encouraged thinking systematically about companies' strategies (Schendel and Cool, 1988).

The seminal work of Chandler (1962), Strategy and Structure, positioned the concept of strategy as a separate business function from marketing, finance, etc. Strategy consisted of deciding on the basic long-term goals of an enterprise and the adoption of the courses of action and allocation of resources necessary for carrying out those goals. In his work, he postulated that 
"structure follows strategy." Strategic decisions were seen to lead to a restructuring of the firm that should yield superior competitive performance.

During the 1960s, two other authors made significant contributions to this new field. One was Igor Ansoff, then general manager of Lockheed Electronics. In his book Corporate Strategy, he argued that strategy is described as a rule for making decisions determined by product/market scope, growth vectors, competitive advantage and synergy (Ansoff, 1965). These concepts and components of strategy, together with the seminal ideas proposed by Chandler (1962), are still explained in strategic management text books and applied, in some way, by most practitioners today.

Other important contributions came from Kenneth Andrews of Harvard Business School, working both alone and with others (Learned et al., 1965; Andrews, 1971). Andrews underlined the importance of business definitions as part of strategy, and the need to determine the company's mission. Andrews developed the SWOT analysis tool to understand how an uncertain environment presents opportunities and threats (OT) to which a firm had to adapt its strengths and weaknesses (SW).

Working together with these scholars, Boston Consulting Group introduced the concept of the "experience curve," and also developed the first analytical tool of portfolio planning, the socalled "Growth/Share Matrix."

Social responsibility and moral values were explicitly considered by pioneers of the strategy concept in the 1960s. Igor Ansoff referred to them in discussing the non-economic influences which affect the objectives of the firm. The personal non-economic objectives that he described "include philanthropy, personal ethics, social responsibilities, social status and reputation" (Ansoff, 1965, p. 65). He added that to understand the influence of these aspects, "the procedure is to single out non-economic influences within the firm which have a strong bearing on the economic objective, and then to assess the extent to which these affect the attributes and the priorities on the firm's master list of objectives" (Ansoff, 1965, p. 65).

Kenneth Andrews (1971) described four integral elements of strategy: “1) market opportunity, 2) corporate competence and resources, 3) personal values and aspirations, and 4) acknowledged obligations to segments of society other than stockholders," (p. 19). Consequently, in designing a strategy, one must define what could be done (opportunities), what can be done (resources), what one considers worth doing (goals) and what should be done (responsibilities).

Andrews insisted that "we must acknowledge at this point that there is no way to divorce the decision determining the most sensible economic strategy for a company from the personal values of those who make the choice" (Andrews, 1971, p. 53). For Andrews, corporations should act following the values of senior managers (personal values), but also paying attention to social issues, and what social and moral leaders are saying (social responsibilities). In his own words, social responsibility has as its reference "the viewpoint of various leaders and segments of society and their own standards of right and wrong" (Andrews, 1971, p. 65).

During the 1960s it was quite common to consider ethics as a matter of "personal values" (for example, Guth and Tagiuri, 1965; and Watson, 1963), instead of considering ethics as a set of universal principles or objective criteria about the right thing to do. Thus, integration of ethics and strategy emerged exclusively from the good will of the decision-maker and on the basis of his or her personal moral values, or possibly through standards coming from moral or social leaders. 
This approach is understandable; at that time, there was widespread subjectivism (ethics reduced to personal values) and moral relativism (ethics reduced to social values). The influential work Administrative Behaviour by Herbet A. Simon, written in 1945, presented this subjectivist view of ethics. Simon recognized the existence of an ethical dimension in the decision-making process, since "decisions are something more than factual propositions (...) they have an ethical as well as a factual content" (Simon, 1976, p. 46). But this acknowledgement did not prevent him from refusing to study those contents. He stated that "scientific propositions (...) are statements about the observable world and the way in which it operates. Ethical propositions, on the other hand, are expressions of preferences" (1976, p. 248). Understanding ethics as preferences, Simon could hardly integrate ethics into business. In Simon's own words: "An administrative science, like any science, is concerned purely with factual statements. There is no place for ethical assertions in the body of a science" (1976, p. 253).

Moved by positivistic philosophy, which carefully separates fact from values, Simon chose to abandon the consideration of values in management science. He thought that for administrative purposes it is enough to consider those values which are attainable and assessable.

One can agree that science is autonomous from ethics, but science is not completely independent of a philosophical and human context. Today, the perspective of positivism that reduces ethics to subjectivity is being seriously questioned. Limiting knowledge to what is empirically verifiable, as positivism suggests, leads one to ignore many aspects of reality that are not directly observable and measurable; yet one can scarcely doubt their existence. This has also been applied to the strategic management context (Godfrey and Hill, 1995). Apart from this, there are also philosophical objections to the methodological roots of positivism. If everything must be verified, then the principle of verifiability itself must be verified as well, yet it remains unverifiable. In other words, the foundation on which scientific rationality rests turns out, paradoxically, to be neither scientific nor rational.

Reducing ethics to mere personal values means that ethics remains outside the rationality of the decision. Since reality is conceived as being devoid of any objective ethical value, obviously this subjective view of ethics, so extrinsic to strategy, has long prevented ethics from being taken seriously by management science. Thus, under the influence of positivism, normative ethical principles were long excluded from the mainstream of business administration.

\section{Integrating Corporate Social Responsibility into Strategic Management}

The 1970s were a time of great turmoil and there was a growing need for strategic thought. World inflation made wages and floating exchange rates volatile, and price control a reality. The dislocations of the 1970s led to the rise of independent firms offering strategic guidance in times when strategic thought and tools for analysis were specially demanded (Oliver, 2002).

The first major conference properly devoted to the subject of strategic management was held in 1977 at the University of Pittsburgh. As a direct result of this conference, the researchers changed the name of the field from strategic planning to strategic management. Contributions from authors such as Rumelt (1974), Ansoff (1979) and Mintzberg (1978) are essential to understanding this period, which may be described as the moment of conceptualization of strategic management. 
The emerging field of strategic management began to feature implementation and evaluation as critical components of organizational success, rather than being preoccupied exclusively with the analysis of the firm and its environment and the formulation of strategies. Strategy researchers could be identified in this period as having strategy content or strategy process approaches. One of the most influential works in content research, in what is the right strategy, was Rumelt's categorization of diversification strategies (Rumelt, 1974). On the other hand, there were authors who were concerned with the understanding of the process of strategy creation, on how to develop a strategy. In this line, Mintzberg (1978) argued that strategy is emergent, rather than just the exercise of planning.

In the U.S. in the 1970s there were social protests related with business and political scandals; meanwhile, Japan began to make huge gains in areas such as electronics and automobiles. Contemporaneously, an important debate on corporate social responsibility (CSR) also took place. This concept was not entirely new. Both academics and practitioners had already considered it in different ways.

Before 1950, some practitioners had already undertaken social initiatives in the business context. Howard Bowen, in 1953, with his influential book Social Responsibilities of the Businessman marked the beginning of corporate social responsibility in academic literature. Bowen explained that the social responsibility of businessmen (at this time the presence of women in management was scarce) "refers to the obligation of businessmen to pursue those policies, to make decisions, or to follow those lines of action which are desirable in terms of the objectives and values of our society" $(1953$, p. 6). Soon many others scholars contributed to developing this idea (Davis, 1960, Cheit, 1964; Davis and Blomstrom, 1966; Steiner 1965, among others) and since then, concern for the social responsibility of business has been relatively frequent in management literature.

In strategic management, as has been mentioned, Andrews had also suggested including social responsibility as a component of strategic decision-making. According to Andrews, leaders and social groups point out to management what the contents of social responsibilities are.

The importance given to social responsibilities during the 1970s linked CSR and strategy; a link based on long-term economic effects and beyond the personal values of managers. Davis (1975) among others, emphasized the risk a company would bear if its behavior was contrary to the expectations of those who constituted the company's social environment.

From the very beginning, proponents of CSR struggled for businesses that were respectful to all, and defended human rights and human conditions in the work place. The most common references, however, were to the "values of our society," "social expectation," "performance expectation," and so forth, instead of "ethical duties" or equivalent expressions. Nevertheless, some authors went further by relating CSR to ethical principles. This is the case of Eells, Walton and Fox, who wrote: "when people talk about corporate social responsibilities they are thinking in terms of the problems that arise when corporate enterprise casts its shadow on the social scene, and of the ethical principles that ought to govern the relationships between the corporation and society" (1961, pp. 457-458). Others scholars changed their position when the business ethics movement emerged in the late 1970s, defending the existence of ethical bases for CSR. This is, for instance, the case of Frederick who in 1960 affirmed that social responsibility "means that businessmen should oversee the operations of an economic system that fulfills the expectations of the public." (p. 60), but some years later wrote a paper in which he strongly defended a CSR with ethical bases. 
For many, both then and now, the base on which social responsibility lies is not one of rational ethics, but what society demands at a given moment. It is worth being familiar with the moral evaluations of people in certain societies, but, strictly speaking, that is not ethical rationality with principles of ethical analysis. As Hosmer points out, "principles of ethical analysis are the means by which a person can objectively determine whether the decisions or actions that either have led or will lead to an expected mixture of benefits and harms are 'right' or 'wrong,' 'just' or 'unjust,' 'fair' or 'unfair.' Ethical principles are not subjective measures that vary with cultural, social, and economic conditions; they are objective statements that transcend countries, religions and times" (1995, p. 20).

It may be stated that in a given society, neither are all social demands ethically correct, nor are all ethical requirements covered by social demands. The study of what is socially accepted or demanded is not ethics but "sociology of ethical beliefs" or "sociological ethics," a tool that may be useful in terms of economic implications and rationality, but also a form of cultural relativism when it reduces ethics to the values that society demands at a given moment (Beauchamp and Bowie, 1997).

Rejecting ethical principles leads to cultural relativism, which is liable to criticism on several grounds (Donaldson, 1989; Hoffman and Frederick, 1995). The fundamental difficulty with cultural relativism is its confusion of social facts and moral norms. The facts, determined by sociology, indicate what is permitted or demanded in a society, for the sake of custom or convenience, whereas moral norms concern what ought to be done according to rational principles, and not only by custom. Social demands and the ethical evaluation of social consequences of companies' behavior are different, but both can be present in the same decision making process. Nevertheless, the cultural relativism approach neglects any integration of ethical social judgment with sociological economic evaluation.

Although corporate social responsibilities were accepted by many companies, some critical voices against this concept soon arose. The best-known opponent was Milton Friedman. He stated that "there is one and only one social responsibility of business - to use resources and engage in activities designed to increase its profits so long as it stays within the rules of the game, which is to say, engages in open and free competition, without deception or fraud." (Friedman and Friedman, 1962, p. 133)

In Friedman's position is against corporate social responsibility, by reducing the social function of business to the benefit of stockholders, but he did not in the least deny a certain role of ethics. He considered the obligation of managers to fulfill their fiduciary duties towards the shareholders, and to compliance with "the basic rules of society, both those embodied in law and those embodied in ethical custom" (Friedman, 1970/1993, p. 249), in addition to following the rules of free competition, without deception or fraud.

In Friedman's view of the purpose of business, ethical matters - understood as a few basic norms (avoid fraud, honor contracts) and maybe some more ethical customs - are seen as constraints to economic results. In essence, this position had been already presented by Ansoff. This author explained that the objective of a firm is to maximize economic returns. Regarding responsibilities, he stated that "since responsibilities do not interact with the firm's choice of products and markets in the strategy formulation process, they can be treated as constraints. The distinction between constraints and objectives resides in the fact that the former represent the limits within which the firm must operate, whereas the latter are the goals which the firm strives to attain" (Ansoff, 1965, p.59). 
From Freidman's approach two questions arise. First, whether business only has the responsibility of wealth creation. Second, whether ethics can be reduced to legal regulations and a few ethical norms that are taken from the social environment of a business, and which would be introduced into strategic thought in terms of economic rationality and as external constraints.

\section{Corporate Social Responsiveness and Stakeholder Management}

The notion of corporate social responsibility, considered to be overly abstract and generic, began to be replaced, or complemented, by that of "corporate social responsiveness" during the second part of the 1970s (Ackerman, 1973; Ackerman and Bauer, 1976; Sethi, 1975; Bowman and Haire, 1975). The idea of social responsiveness is that business must not only respond to, but must also anticipate public concerns. The concrete demands of society have to be discovered and answered. The proponents of this concept sketched out a new, more pragmatic way of linking strategy with society's expectations and demands, in a manner that could contribute more explicitly to the benefit of the organization, or in Porter's terminology, to attaining competitive advantage.

Later, during the 1980s, several authors developed the ideas of "corporate social responsiveness" in strategic management, trying to quickly respond to any social demand or, even more, to be proactive (Ansoff, 1982; Arcelus and Schaefer, 1982; Mintzberg, 1983; Carroll and Hoy, 1984; Daneke and Lemak, 1985; Milles, 1987; Meznar, et al. 1991, among others).

The theory of social responsiveness constitutes another attempt to integrate ethics and strategy, but this attempt at integration still has the same problems as those described in the previous approach to corporate social responsibility. This way of formulating strategy, although it can include some ethical issues, is not properly a form of ethical reasoning. Attentiveness to the demands of society is important, and may contribute to attaining competitive advantage, but a response grounded exclusively on those demands contains no guarantee of ethical correctness.

A comprehensive idea, which includes both corporate social responsibility and corporate social responsiveness, is the concept of "corporate social performance" (CSP) which was introduced by Carroll in 1979. Wood (1991) presented a model of corporate social performance composed of principles of CSR, processes of corporate social responsiveness and outcomes of corporate behavior. The principles included: principles of CSR expressed at the institutional, organizational and individual levels; processes of corporate social responsiveness, such as environmental assessment, stakeholder management and issues management; and the outcomes of corporate behavior, including social impacts, social programs and social policies.

This group of theories, integrated within the concept of CSP, looks at how business integrates social demands, arguing that business depends on society for its existence, continuity and growth. The main goal of this model is the detection and scanning of, and response to, social demands, with the aim of achieving social legitimacy, greater social acceptance and prestige. Social prestige can be a source of stable competitive advantage, from a resource-based view of the firm.

In this context, during the 1980s the need to consider the interests of all groups of people with a specific stake in the firm was suggested. Freeman (1984) tried to join strategic management with stakeholder interests. In his book Strategic Management: A Stakeholder Approach, he 
defined stakeholders as "any group or individual who can affect or is affected by the achievement of an organisation's objectives” (1984, p. 46).

The stakeholder approach came when the business ethics movement had just started, in the late 1970s. At that time, business ethicists focused their attention mainly on ethical principles and applying ethical theories to making moral judgments regarding decisions. Principled ethical theories gave an element of objectivity to social and ethical issues, since as Hosmer (1995) pointed out, it is necessary to distinguish between "moral standards," "value judgments" and "ethical principles." The first two are subjective, variable and liable to cultural influences: religious, social and economic. Only ethical principles are "objective, consistent and timeless" (p. 24).

In this context, Freeman and collaborators developed a stakeholder approach to strategic management based on ethical theories (see Phillips, 2003, for a recent review of this theory). Many proponents of the stakeholder approach took, as their starting point, the idea that the manager bears a fiduciary relationship to stakeholders, instead of having exclusively fiduciary duties towards stockholders, as was held by those with a conventional view of the firm. Thus, responsible management would require simultaneous attention to the legitimate interests of all appropriate stakeholders and, as such, should balance a multiplicity of interests and not only the interests of the firm's stockholders. In order to point out how corporations should be governed and how managers ought to act, a normative core of ethical principles is required (Freeman, 1984). To this end, various scholars have proposed normative ethical theories, including Kantianism, fair contract theory, feminist ethics and others (Phillips, 2003).

Freeman and Gilbert (1988) defended the idea that ethics is an intrinsic element of business life, and championed the union of ethics with strategic management though the stakeholder theory. These scholars proposed that strategies should honor a principle of personal autonomy and a principle of voluntary agreement. Gilbert (1992) added that strategy should be inseparable from a person's ethical responsibility to contribute to human solidarity.

Since the 1980s, stakeholder theory has spread considerably, and the bibliography available is quite extensive. The stakeholder approach constitutes a step forward in the understanding of ethics and strategy connections. Ethical principles give a sense of rationality to social responsibilities, avoiding the problem mentioned earlier of taking norms exclusively from social values or demands. They also introduce the possibility of giving a reasoned answer to demagogic social demands.

Freeman and Gilbert (1988) made an excellent contribution; however their vision has also been criticized for reducing the business world simply to a group of self-existing personal projects, neglecting the role of corporate culture (Mulligan, 1992). Apart from this, normative stakeholder theory has suffered critical distortions and friendly misinterpretations, which Freeman and co-workers are trying to clarify (Phillips et al., 2003).

A stakeholder approach grounded in ethical theories presents a perspective of corporate social responsibility in which ethics is central. This represents clear progress in the understanding of the integration of ethics into strategic management. In fact, there is a connection between strategic thought and ethical reasoning. However, some questions still arise from the stakeholder proposal. Does the manager have an identical fiduciary relationship with each of the stakeholders? Does respect for people require that the groups must somehow participate in decisions that substantially affect their welfare, as some authors propose? Is the very purpose of 
the firm to serve as a vehicle for coordinating stakeholder interests? It is not easy to give completely satisfactory answers to these questions.

The stakeholder theory does not use "social values" but rational ethics. This could apparently be a way to overcome ethical relativism. In fact, Freeman and Gilbert (1988) considered the dangers of ethical relativism and tried to overcome them by means of ethical principles. In their work Corporate Strategy and the Search for Ethics, they wrote: "Even if you ultimately believe some form of relativism (our efforts to the contrary), we want to show you how you still need to learn to reason about moral principles and their connection to actual business strategy decisions" (1988, p.24). However, in practice, relativism is only partly overcome by this approach, since many different rationalistic ethical theories can be used within stakeholder theory, as E.R. Freeman himself has recognized, by saying: "The stakeholder theory' can be unpacked into a number of stakeholder theories, each of which has a 'normative core,' inextricably linked to the way that corporation should be governed and the way that managers act" (1994, p. 413). Thus, the ethical consideration of new social aspects and actors is not enough to avoid relativism. If ethical rational judgment is not considered at managerial level, in every decision not only those related with stakeholders, and also, if the managers' actions are not ethical (right, just or fair), then the problem of relativism will remain.

Stakeholder theory certainly doesn't overcome relativism. On the contrary, it runs the risk of being trapped in what Solomon (1992b, p. 318) called an "unabashed relativism" ("if you are utilitarian, you'll do this; if you're Kantian, you'll do that”).

\section{The Industrial Organizational Economics View and Strategic Corporate Social Responsibility}

The decade of the 1980s was a period in which strategic management again offered an important contribution to the managerial world. It was a period of relative political tranquility in the U.S., but massive changes overseas. Some elements that may explain the dynamism and complexity of the environment in this decade are, among others, the political liberalization of Eastern Europe by the second half of the decade, the market liberalization in Asia and Latin America, or the formation of trading groups in Europe, together with the imitation of the Japanese business model by leading firms all around the world (Oliver, 2002).

At this historical moment, the ideas of Michael Porter's books Competitive Strategy (1980) and Competitive Advantage (1985) provided substantive guidance to analysts, consultants and managers. Some argued that his books were the legitimization of strategy as an academic discipline. In particular, his "five forces industry analysis" and the "generic strategies" described in the books are considered the most influential contributions of strategic thought at this time (Barney, 2002).

Porter's model, which imported ideas from industrial organizational economics, is based on a structure-conduct-performance logic. According to this model, company performance is determined by industry structure attractiveness, which depends on five essential forces: threat of entry, intensity of rivalry among competitors, pressure from substitute products, bargaining power of buyers, and bargaining power of suppliers. Therefore, potential profit relates directly to the combined strength of these forces. The model will help firm conduct within the industry 
structure, and companies may use three main generic strategies (strategic choice) to earn superior returns: overall cost leadership, differentiation and focus.

This model was adopted in empirical research, included as part of strategy textbooks and implemented in the world of business. In fact, it started a new era of research. A large number of studies examined the efficacy of generic strategies during the 1980s, continuing the strategy content approach to the discipline. In the meantime, strategy process researchers, based on Porter's ideas, also expanded into more sophisticated conceptualizations and areas of research connecting with other influential approaches.

Strategic management thought, in this period, started a dialog with other influential theories in management, like institutional theories (Meyer and Rowan, 1977), political approaches (Pfeffer and Salancik, 1978), or the environmental approach of population ecology (Hannan and Freeman, 1977). At least ten schools of thought on strategy formation had been described by the 1980s, and, although some criticized Porter's positioning school as too narrow a perspective, most writers in this area would agree that his work must be counted as having made a major contribution to strategic thought in that decade (Mintzberg, 1990).

Porter's theories also remained vital during the decade of the 1990s, especially the "value chain" concept, a tool for internal transaction value analysis. Consulting firms like McKinsey extended this concept by developing value system analysis models. This new decade was characterized by the turbulence of an environment with higher levels of competitiveness, entrepreneurship and innovation. It was in the 1990s that Internet started to change the role of customers in their relationships with business. Also present was an increasing emergence of sophisticated information technologies, with the creation of complex technical systems for internal and external strategic purposes. Since then, much strategy discussion has ranged around building competences to support such systems internally and through alliances with key partners (Oliver, 2002).

In contrast with the 1970s managerial view of including CSR in strategy formulations, the industrial organization economics approach, and more specifically, Porter's industry analysis approach, are more in line with the idea of Friedman (1970) that the corporation should act exclusively in the interests of stockholders. Porter $(1980,1985)$, by looking at the five forces affecting competition within industries, didn't care about seniors' values or social values or ethical principles. The only concern of Porter's approach was to create strategies to achieve competitive advantages. There was no room for ethics, and the only connection with CSR was in using it to get competitive advantage and only when this was possible.

However, Porter today, along with other scholars who are in line with Milton Friedman, agrees in accepting what Burke and Logsdon (1996) have called "strategic corporate social responsibility" (SCSR). This refers to policies, programs and processes which yield "substantial business related benefits to the firm, in particular by supporting core business activities and thus contributing to the firm's effectiveness in accomplishing its mission.” (p. 496). These CSRs are accepted as "enlightened value maximization," since they lead to long-term value maximization or value-seeking as the firm's objective (Jensen, 2000). In this line, Porter and Kramer have affirmed that "philanthropic investments by members of clusters, either individually or collectively, can have a powerful effect on the cluster competitiveness and the performance of all its constituent companies” (Porter and Kramer, 2002, pp. 60-61).

This approach is far from integrating ethics and strategic management. CSR, when it is accepted, is seen exclusively as an instrument for value maximization. 


\section{Resource-Based View of the Firm, Reputation and Competencies}

Technological discontinuities and uncertainties, typical of the 1990s, explain the behavior of firms and the creation of different products or ways of making products, beyond the external analysis of the environment in which a company operates. While previous approaches to strategy neglected, to a great extent, the influence of organizational resources in strategic management, now the resources and capabilities of the companies seemed to be the key element for explaining their success. In this context a new perspective was introduced; the resource-based view of the firm (Wernerfelt, 1984; Barney, 1991). This approach affirms that the main sources of sustainable competitive advantage reside in the development and use of valuable firm resources and capabilities. The key argument is that if resources are valuable, rare and costly to emulate without any close substitutes, then they could become a source of sustained competitive advantage. This perspective complements the industry analysis framework. It is not possible to evaluate the attractiveness of an industry independently of the resources a firm brings to that industry (Barney, 1991). Resources become valuable because of social complexity, an element that was absent in more technical models like Porter's contribution (Grant 1991). Resources that resist imitations, such as culture and reputation, are intangibles, and the result of complex interactions. They become crucial to explaining present competitive advantage. Regardless of the limitations in measuring resources, some empirical studies have statistically tested the original postulates of RBV, confirming the importance of resource sharing among businesses, and especially the association of intangible resources with performance (Herrmann, 2005).

During the 1990s, as we have seen, the field of strategy focused its attention on those resources that are most likely to lead to competitive advantage. The organization should be set up to effectively deploy resources that are valuable, rare, and inimitable. This resource-based view of the firm (Barney, 1991; Wernerfelt, 1984), widely accepted today, maintains that the ability of a firm to perform better than its competitors depends on the unique interplay of human, organizational and physical resources over time. This strategic thought has been complemented with the dynamic aspect of resources ("dynamic capabilities approach"), focused on the drivers behind the creation, evolution and recombination of the resources into new sources of competitive advantage (Teece et al., 1997). Dynamic capabilities are described as the organizational and strategic routines by which managers acquire resources, modify them, integrate them, and recombine them to generate new value-creating strategies.

In this new strategic rationality, some authors have explicitly considered the social and ethical "resources" of the firm, which could be sources of competitive advantage. This explicit consideration has been made at different levels of analysis. At the individual level, the process of moral decision making has been described as a strategic asset, a decisive component explaining the integrity of the firm (Petrick and Quinn, 2001). At the organizational level of analysis, the corporate positive image, which includes reputation for being socially responsible, has received special attention as a source of competitive advantage (Barney, 1991).

When the analysis of the resources and capabilities is carried out at an institutional level, in terms of the relationship of the organization with the rest of society, then the processes of perception, deliberation and responsiveness of the organization or its capacity for adaptation becomes another source of competitive advantage (Litz, 1996). This capacity for adaptation is directly related to the concept of corporate social responsiveness already developed in the earlier literature. 
Another source of competitive advantage is the ability of the firm to build proper relationships with the primary stakeholders: shareholders, employees, customers, suppliers, and communities (Harrison and St. John, 1996; Hillman and Keim, 2001). A connection between stakeholder theory and the resource-based view of the firm has been presented more accurately by Hart (1995). He has created a conceptual framework that includes among the most important drivers for new resources and capabilities the sustainable development of the firm. He considers three critical resources of a firm: continuous improvement, stakeholder integration and shared vision.

To sum up, there was a growing interest in social and ethical aspects in the strategic management literature during the 1990s. Ethical issues were considered at different levels of strategic analysis (personal, organizational and institutional) and were included within the logic of strategic thought, mostly in terms of its contribution to valuable future competitive advantage.

Consequently, most attempts at linking ethics or social responsibilities with strategic management have been made under the explicit consideration of their contribution to longterm economic results. Ethical integrity, reputation or stakeholders' concerns could contribute to the creation of a stable competitive advantage. Ethical rationality, when it is considered, is subordinated to strategic management rationality. In other words, no specific action that management is responsible for performing throughout time, in each industry, is considered. Thus ethical judgments are still seen as relative and subject to economic rationality. If ethical issues are sources of competitive advantage they will be taken into account, not for their own sake, not for their intrinsic value but only for economic reasons.

\section{Toward a More Comprehensive Integration of Ethics in Strategic Management}

Table II schemes a historical evolution of how business ethics and corporate social responsibility have been incorporate into strategic management. In the first decade of the twenty-first century, the integration of ethics and social responsibility within the logic of strategic management has not changed substantially, and most of the contributions refer explicitly to ethical aspects because of their contribution to final results in terms of economic rationality. However, the role that ethical issues are playing today is wider than few decades ago. As some authors have argued, today strategic management should develop dominant designs that allow firms to create communities in which increasingly participative consumers interact with the firms' stakeholders and help to create value (Herrmann, 2005). The very logic of economic relationships, inside and outside the firm, includes stakeholder contributions and their implications for the creation of value. 


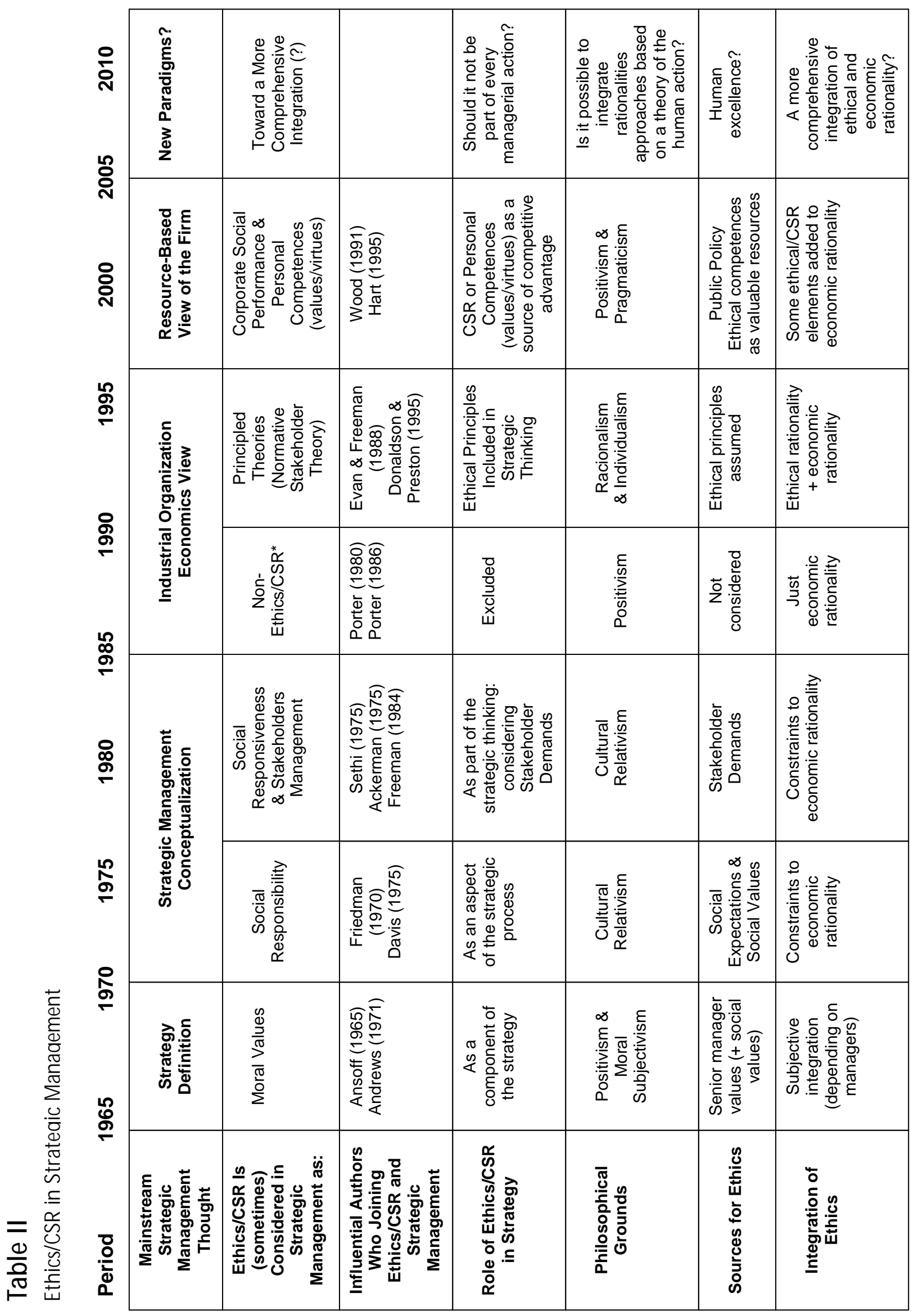

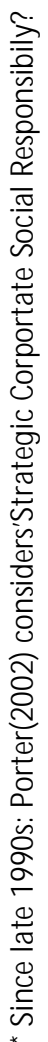


The new strategic paradigm that is demanded from scholars requires the creation of experience environments in which consumers co-create value by constant interaction with networks of companies that pull together large numbers of suppliers, partners and consumer communities (Prahalad and Ramaswamy 2003). Within this perspective of common creation of value, attaining stakeholder trust will be crucial; and the advantages born from the trust generated by acting ethically will have important consequences. If Hosmer's (1995) logic about trust was right about the new challenging strategic management era, it will be necessary to better understand the logic of ethical behavior.

Not only at the level of institutional relationships, but also at the organizational and personal levels, new changing circumstances require that firms develop self-sustaining systems which empower employees through structures that are now democratic, and also through values that are communal and through individual practices focused on engagement (Manville and Ober, 2003). Ethical behavior and its contribution to best practices will have important implications for the level of discretionary effort of individuals and their contribution to the creation of value, but also for the process of learning and attitudes to being innovative. It seems crucial to integrate people into new conceived learning organizations. In fact, the attention of the researchers in the field of strategy was focused first on the environment, then on the firm, and now on the human potential of individuals (Hoskisson et al., 1999).

But probably the most important challenge for the new strategic paradigm at every level of analysis will be a better understanding of strategic rationality and its relationship with an ethical or moral rationality. At this point, the ideas expounded by Singer (1994) in his article "Strategy as Moral Philosophy" could shed light on the question. He identifies and classifies a great many types of "rationality" - more than forty of them, mostly economic - which directly inform strategy. The question then arises: do moral types of rationality also have a role to play within the framework of strategy? Singer makes clear that the meeting point between strategy and rationality is human action itself. On this basis, since the moral kind is only one of so many "rationalities," Singer concludes: "If strategy and rationality are both broadly concerned with problems of action, decision and behavior set in socioeconomic contexts, then so too are ethics and the broad discipline of moral philosophy" (Singer, 1994: 200). We can therefore say that rationality, and within it, "moral rationality" - ethics - constitutes part of strategy's own logic.

If the link between ethics and strategy has to be found in every managerial action, and not in an external juxtaposition of the two concepts, then an accurate study of human action, taking its dynamism into consideration, may be crucial to achieve a proper integration of ethics and strategic management. That seems to be a challenge for further research.

The "amoral" rationality implicitly sustained by many strategic theories can no longer persist. As Ghoshal (2005) suggested in one of his final contributions to the field of strategic management, by propagating ideologically inspired amoral theories, business schools have actively freed their students from any sense of moral responsibility. He argues that academic research related to the conduct of management has had some very significant and negative influences on the practice of management.

Researchers and executives have to accept the fact that the ethical impact of their decisions and behavior will rarely, if ever, be neutral. Both, ethical rationality and ethical behavior in business can no longer be ignored (Thomas et al. 2004). 
Strategic decision making necessarily has one ethical and another economic end, as has been admitted, although somehow ignored, by many of the strategy writers. Instrumental and ethical rationality have to be distinct, yet interdependent. They can be distinguished between, but only artificially separated. In the real world of management, both economic and ethical rationality are present in every managerial act. And this being the case, a more comprehensive integration of ethics and strategic management should consider both economic and ethical rationalities (Singer, 1994). Both can be said to be part of the global rationality of human action.

Economics focuses on the useful good, or goal, to be attained. This good is instrumental: it is not desired for its own sake, as human good is, but for its utility in attaining another further end (Simon, 1945). This is why the useful good (economics) should be oriented to the human good (ethics), and not the other way around. However, human action is one and the same. One performs an action with an eye to certain results (making something): in this respect, strategy requires instrumental rationality (useful good). At the same time, however, it is a human action which demands ethical rationality (human good).

With this interdependence and unity of action in mind, a "global rationality" would comprise instrumental rationality, ethical rationality and their mutual dependence. If every managerial decision constitutes a human action, then it ought to respond to a "global rationality," one with a view to the logic of "acting" as well as that of "making." To stop at the latter would be reductionism, a partial view of reality. In the real world of business there is no strategy without action and none, therefore, without ethics. But action in business demands not only "making," but also "doing:" otherwise, it would be deprived of a necessary support.

The action of selling, for instance, from the perspective of "making," could be evaluated as an efficient sale, a successful sale, one with a satisfied client, or according to any other resultoriented aspect. But from the perspective of "acting," we call it a good sale if it was just; otherwise, we call it a fraud. The acting remains within the agent who operates, whereas the making is an operation that passes on to the material external to him: something is formed by means of the action.

This distinction was first described by Aristotle, and later agreed with by many philosophers. Both kinds of rationality "making and acting are different (for their nature we treat even the discussions outside our school as reliable); so that the reasoned state of capacity to act is different from the reasoned state of capacity to make!" (Aristotle, Nicomachean Ethics, VI, 4, 1140a). Hence, neither one is subsumed into the other: action is not production, nor production action.

An example may clarify how both kinds of rationality work. When we assert that a "good" counterfeit bill is one that has come out "well," we are employing "making" rationality: the one that judges whether, "technically speaking," the counterfeiting is "good" (technical quality), but does not allow us to judge whether the action of counterfeiting bills is good in an ethical sense (moral quality). "Acting" rationality, by contrast, has to do with the action in itself. It is not the same thing to make counterfeit bills for use in a film, or for some other inoffensive activity, as it is to make them for use in a swindle. This rationality involves an ethical evaluation of the action which has nothing to do with the rational evaluation of the "technical" effectiveness of the product (the effectiveness which produces counterfeit currency that will pass for legal tender). This discernment of the action's morality is a response to an "ethical rationality" that is as much an element of human action as "instrumental rationality" can be. The reduction of managerial decisions to instrumental rationality constitutes the elimination of ethically 
objective judgments about right or wrong decisions from the arena of managerial decisions. Only the consideration and the understanding of both kinds of rationality, as part of a "global rationality" of managerial behavior, seems to be a sound way to avoid "amoral" approaches to management theories.

Understanding managerial action according to a "global rationality" would allow the manager to integrate his "instrumental" (effectiveness-oriented) strategy judgments and his "ethical" (morality-oriented) ones. According to the logic of "global rationality," only acting well in a simultaneously technical and moral sense can lead to genuine trust. The two essentially distinct but interdependent rationalities - the "instrumental" and the "ethical" - come together in strategic action. Our proposal for a more comprehensive integration of ethics in strategic management is a "global rationality" which would integrate the two.

Ethical rationality oriented to human excellence is an open rationality, continuously ready to know what is meant by a proper human good that generates human excellence (Solomon, 1992a, 1999). Understanding human good is the responsibility of each individual but it is also the responsibility of those who govern or are involved in communities. When it is necessary to search for common goods for communities, a sincere dialogue seems absolutely necessary to look for true human and social goods. The human rights declarations and the "golden rule" are good examples of how common people can agree on some basic common morality.

The consideration of a "global rationality" including "instrumental" and "ethical" rationality views the design and development of strategy as human actions with repercussions for the decision maker's own person (moral character) and for all those affected by the decision. External results and human development are mutually involved as integral components of the logic of action. This may explain why ethical behaviors are able to create strategic leadership and trust (Thomas, et al., 2004; Davis et al., 2000).

If ethical rationality constitutes part of a strategy's own logic (Singer, 1994), then the understanding of both ethical and strategic rationality in managerial action becomes a real challenge for scholars and practitioners alike.

\section{Conclusions}

All things considered, we have to say that a sound integration of ethics and strategy in terms of rationality, remains unsolved. The best accepted contributions, from the field of ethics to that of strategic thought, are rooted in economic rationality. Ethical aspects mostly constitute subjective additions, sociological restrictions, external obligations or valuable considerations attached and subordinated to economic rationality.

Current attempts at integration are valuable contributions which throw light on various partial aspects of the problem. However, in these proposals, the connection between ethics and strategy fails to move beyond an arbitrary superposition of ethical elements to the usual logic of economics, whether to achieve the best results with fewest resources or to introduce normative limits to economic rationality.

The sense of responsibility adopted in the theories discussed, and the values assumed (psychological perceptions, social evaluations, leaders' opinions) rest on shaky ground. Ethicsstrategy links based on the profitability of ethics are very weak. If ethical requirements should cease to contribute to the decision maker's interests or benefit, this would be sufficient reason 
to abandon ethics. Even attempts to introduce universal ethical principles of a rationalist kind are not enough, since they employ theories whose rationality does not sufficiently take the logic of action into account. Besides, the choice of which ethical theory to employ - some are incompatible with others in their deontological or utilitarian approaches - is left to the decision maker's whim.

Ethics is not a part of a business strategy for the achievement of certain goals. Nor should strategy be confused with ethics. Aristotelian tradition and common sense show that ethics is part of the logic of human action. Apart from developing decision-maker competencies, ethical actions contribute to fostering trust and a sense of collaboration in those involved in the action. This tends to work in favor of future business results.

An open-minded attitude seems to us crucial for the investigation of business in its totality. One could thus overcome positivism with its radical split between facts and values, its consequent reduction of ethics to personal values, and the disjunction between ethics - thus understood - and business management.

In order to grasp the place of ethics in managerial action, one must delve into the rationality of human action, or a "global rationality" in which both technical rationality and ethics are present. To settle for less would be to reduce human action to a merely mechanical process. Furthermore, we cannot speak of a moral judgment about whether a given action is right or wrong as long as theories fail to overcome the threats of relativism at the basis of most of the integration attempts, which give rise to a confusion of observed ethical behavior and correctly formulated ethical norms.

A review of the concept of rationality upheld here would open the door to integrative theories in which ethical goals could be considered as part of managerial decisions, together with ethical norms and also with ethical practices (virtues), all of them affecting economic results, but also affecting other spheres of human behavior.

The challenges mentioned may have serious implications for theory and research, and will require an interdisciplinary approach that includes management and ethics. The review of managers' rationality as a global rationality within the logic of "human action" seems to be the key to this, providing a framework within which management and moral philosophy are both present. This, we think, is a challenge of perhaps very great theoretical and practical weight: one which, in our judgment, requires us to move beyond the present fragmentation of knowledge, but necessary if the amorality of management is to be surpassed.

These challenges also contain implications for the manager, especially regarding the importance they have for the development of the manager's moral character. Insofar as this character is recognized it will be valued and fostered. If, on the other hand, a notion of managerial action is inspired exclusively by a rationality that looks merely at external results, ignoring an action's effects on the agent her or himself and on others, no attention will be paid to the development of the moral dimension of managerial action itself.

Finally, in light of the point just made, the challenges that emerge from this research can serve as a reference point for reflection on the education offered to managers in business schools. The integration of ethics and strategy suggests that we should include the ethical dimension in the resolution of any strategic management case as a decision criterion - as we do with the economic dimension - instead of relegating it only to cases of extreme ethical dilemmas, as is usually done today. 


\section{References}

Ackerman, R.W. (1973). "How Companies Respond to Social Demands," Harvard University Review, 51(4): 88-98.

Ackerman, R.W. and Bawer, R.A. (1976). Corporate social responsiveness, Reston Publishing, Reston, VA.

Andrews, K.R. (1971). The Concept of Corporate Strategy, H. Dow Jones-Irwin, Homewood, IL.

Ansoff, H.I. (1965). Corporate Strategy: An Analytical Approach to Business Policy for Growth and Expansion, McGraw-Hill, New York.

Ansoff, H.I. (1979). A Concept of Corporate Planning, Wiley, New York.

Ansoff, H.I. (1982). "Societal strategy for the business firm," In Ansoff, Bosman and Storm (eds.), Understanding and managing strategic change, Norh-Holland, pp. 83-109.

Arcelus, F.J. and Schaefer, N.V. (1982). "Social demands as strategic issues: some conceptual problems," Strategic M anagement J ournal, 3, (4), 347-357.

Aristotle. (1925). The Nicomachean Ethics, (D. Ross, Trans.), Oxford University Press, Oxford New York. Also published in World's Classics collection, 1980.

Barney, J.B. (1991). "Firm Resource and Sustained Competitive Advantage," J ournal of Management 17: 99-120.

Barney, J.B. (2002). "Strategic management: from informed conversation to academic discipline," A cademy of Management Executive, 16(2): 53- 57.

Beauchamp, T.L. and Bowie, N.E. (1997). Ethical theory and business (5th ed.), Prentice-Hall, Englewood Cliffs, NJ.

Bowen, H.R. (1953). Social Responsibilities of the Businessman, Harper and Row, New York.

Bowman, E.H. and Haire, H. (1975). "A Strategic Posture Toward Corporate Social Responsibility,” California Management Review, 18: 49-58.

Burke, L. and J.M. Logsdon (1996). "How Corporate Social Responsibility Pays Off," Long Range Planning 29(4): 495-503.

Carroll, A.B. (1979). "A Three-Dimensional Conceptual Model of Corporate Performance," A cademy of Management Review 4(4): 497-505.

Carroll, A.B. and Hoy, F. (1984). "Integrating corporate social policy into strategic management," J ournal of Business Strategy, 4 (3): 48-57.

Chandler, A.D. (1962). Strategy and Structure: Chapters in the History of the Industrial Entreprise, The M.I.T. Press, Cambridge.

Cheit, E.F. (1964). The business establishment, Wiley, New York.

Daneke, G.A. and Lemak, D.J. (1985). "Integrating strategic management and social responsibility," Business Forum, 10, (2-3): 20-25. 
Davis, K. (1960). “Can Business Afford to Ignore Corporate Social Responsibilities?” California Management Review 2: 70-76.

Davis, K. and Blomstrom, R.L. (1966). Business and its Environment, McGraw-Hill, New York.

Davis, K. (1975). "Five Propositions for Social Responsibility,” Business Horizons, 18 (3): 19-24.

Davis, J.H., Schoorman, F.D., Mayer, R.C. and Tan H.H. (2000). "The trusted general manager and business unit performance: Empirical evidence of a competitive advantage," Strategic Management J ournal, 21 (5): 563-576.

Donaldson, T. (1989). The ethics of international business, Oxford University Press, New York.

Eells, R., Walton, C., and Fox, S. (1961). Conceptual foundations of business: an outline of major ideas sustaining business enterprise in the Western World, R.D. Irwin, Homewood Ill.

Frederick, W.C. (1960). "The growing concern over business responsibility," California Management Review, 2: 54-61.

Freeman, R.E. (1984). Strategic Management: A Stakeholder A pproach, Pitman, Boston.

Freeman, R.E. and D.R. Gilbert Jr. (1988). Corporate Strategy and the Search for Ethics, Prentice-Hall, Englewood Cliffs, NJ.

Freeman, R.E. (1994). "The Politics of Stakeholder Theory: Some Future Directions," Business Ethics Quarterly, 4 (4): 409-429.

Friedman, M., and Friedman, R. (1962). Capitalism and Freedom. University of Chicago Press, Chicago.

Friedman, M. (1970/1993). "The Social Responsibility of Business Is to Increase its Profits," in G.D. Chryssides and J.H. Kaler (eds.), An Introduction to Business Ethics, Thomson Learning, London, 249-254. First published in New York Times Magazine, 13 September 1970, pp. 32-33, 122-126.

Gilbert, D.R.J. (1992). The Twilight of Corporate Strategy. A Comparative Ethical Critique, Oxford University Press, New York - Oxford.

Ghoshal, S. (2005). “Bad Management Theories Are Destroying Good Management," A cademy of Management Learning and Education, 4 (1): 75-91.

Godfrey, P.C. and Hill, C.W. (1995). "The problem of unobservables in strategic management research," Strategic Management J ournal, 16: 519-533.

Guth, W.D. and R. Tagiuri (1965). "Personal Values and Corporate Strategy," Harvard Business Review 43(5): 123-132.

Grant, R. (1991). “Porter's 'Competitive advantage of nations:' an assessment," Strategic Management J ournal, 12: 535-548.

Hannan, M.T. and Freeman, J. (1977). "The population ecology of organizations," American Journal of Sociology, 82: 929-964.

Harrison, J.S., and St. John, C.H. (1996). "Managing and Partnering with External Stakeholders," A cademy of M anagement Executive, 10(2): 46-61. 
Hart, S.L. (1995). “A Natural-Resource-Based View of the Firm," Academy of Management Review 20 (4): 986-1012.

Herrmann, P. (2005). "Evolution of strategic management: The need for new dominant designs," International J ournal of Management Reviews 7 (2): 111-130.

Hillman, A.J. and Keim, G.D. (2001). "Shareholder Value, Stakeholder Management, and Social Issues: What's the Bottom Line," Strategic Management J ournal, 22(2): 125-140.

Hoffman, W.M. and Frederick, R.E. (1995). Business Ethics. Readings and Cases in Corporate M orality, $3^{\text {rd }}$ ed., McGraw-Hill, New York.

Hosmer, L.T. (1995). "Trust: The Connecting Link Between Organizational Theory and Philosophical Ethics," A cademy of Management Review, 20(2): 373-397.

Hoskisson, R.E., Hitt, M.A., Wan, W.P., and Yiu, D. (1999). "Theory and research in strategic management: Swings of a pendulum," J ournal of Management, 25(3): 417-456.

Jensen, M.C. (2000). "Value Maximization, Stakeholder Theory, and the Corporate Objective Function," In M. Beer and N. Nohria (eds.), Breaking the Code of Change, Harvard Business School Press, Boston: 37-58.

Learned, E.P., Christensen, C.R., Andrews, K.R., and Guth, W.D. (1965). Business policy: Text and cases, Richard D. Irwin, Homewood, Ill.

Litz, R.A. (1996). "A Resourced-Based-View of the Socially Responsible Firm: Stakeholder Interdependence, Ethical Awareness, and Issue Responsiveness as Strategic Assets," Journal of Business Ethics, 15: 1355-1363.

Manville, B., and Ober, J. (2003). A Company of Citizens, Harvard Business School Press, Boston.

Meznar, M.B., Chrisman, J.J., Carroll, A.B. (1991). "Social responsibility and strategic management: toward an enterprise strategy classification," Business and Professional Ethics J ournal, 10, 1: 47-66.

Meyer, J.W. and Rowan, B. (1977). "Institutionalized organizations: formal structure as myth and ceremony," A merican J ournal of Sociology, 83: 340-363.

Milles, R.A. (1987). Managing the corporate social environment, Prentice-Hall, Englewood Cliffs, NJ.

Mintzberg, H. (1978). “Patterns in Strategy Formation,” M anagement Science, 24(9): 934-948.

Mintzberg, H. (1983). "The case for corporate social responsibility," Journal of Business Strategy, 4, (2): 3-15.

Mintzberg, H. (1990). "Strategy Formation: Schools of Thought," In Fredrickson, J.W. (ed.) (1990): Perspectives on Strategic M anagement, Harper Business, New York: 105-235.

Mulligan, T.M. (1992). “Corporate Strategy and the Search for Ethics (Book Review)," J ournal of Business Ethics 11(7): 514-554.

Oliver, R.W. (2002). "The Future of Strategy: Historic Prologue,” J ournal of Business Strategy, 23(4): 6-9. 
Petrick, J. and Quinn, J. (2001). "The Challenge of Leadership Accountability for Integrity Capacity as a Strategic Asset," J ournal of Business Ethics, 34: 331-343.

Pfeffer, J. and Salancik, G.R. (1978). The External Control of Organizations: A Resource Dependence Perspective, Harper and Row, New York.

Phillips, R.A. (2003). Stakeholder Theory and Organizational Ethics, Berrett-Koehler, San Francisco.

Phillips, R.A., Freeman, E. and Wicks, A.C. (2003). "What Stakeholder Theory Is Not," Business Ethics Quarterly 13 (1): 479-502.

Porter, M.E. (1980). Competitive Strategy: Techniques for A nalyzing Industries and Competitors, Free Press, New York.

Porter, M.E. (1985). The competitive advantage of nations, Free Press, New York.

Porter, M.E. and M.R. Kramer: (2002). "The Competitive Advantage of Corporate Philanthropy,” Harvard Business Review 80(12): 56-69.

Prahalad, C.K., and Ramaswamy, V. (2003). "The New Frontier of Experience Innovation," MIT Sloan Management Review, 44(4): 12-18.

Ramos-Rodríguez, A.R. and J. Ruíz-Navarro (2004). "Changes in the intellectual structure of strategic management research: A bibliometric study of the Strategic Management Journal, 1980-2000," Strategic M anagement J ournal 25: 981-1004.

Rumelt, R.P. (1974/1986). Strategy, structure, and economic performance, (2nd ed.), Harvard Business School Press, Boston.

Schendel, D. and Cool, K.O. (1988), "Development of the strategic management field: some accomplishments and challenges," in Grant, J.H. (eds.), Strategic Management Frontiers, JAI Press, Greenwich, CA: 17-31.

Sethi, S.P. (1975). "Dimensions of Corporate Social Performance: An Analytical Framework," California Management Review, 17 (3): 58-64.

Singer, A.E. (1994). "Strategy as moral philosophy," Strategic Management J ournal, 15(3): 191213.

Simon, H. (1945/1976). Administrative behavior. A study of decision-making processes in administrative organization, $3^{\text {rd }}$ ed., Macmillan Free Press, New York. (First edition: 1945, Macmillan, New York).

Solomon, R.C. (1992a). Ethics and excellence: Cooperation and integrity in business, Oxford University Press, Oxford.

Solomon, R.C. (1992b). "Corporate Roles, Personal Virtues: An Aristotelian Approach to Business Ethics,” Business Ethics Quarterly, 2(3): 317-339.

Solomon, R.C. (1999). A better way to think about business, Oxford University Press, Oxford.

Steiner, G. (1965). Business and society, (2 ${ }^{\text {nd }}$ ed.), McGraw-Hill, New York. 
Teece, D.J., Pisano, G., and Shuen, A. (1997). "Dynamic Capabilities and Strategic Management," Strategic M anagement J ournal, 18(7): 509-533.

Thomas, T., Schermerhorn, J.R. and Dienhart, J.W. (2004). "Strategic leadership of ethical behavior in business," The A cademy of M anagement Executive, 18 (2): 56.

Watson, T.J. (1963/2003). A business and its beliefs: the ideas that helped build IBM, McGrawHill, New York.

Wernerfelt, B. (1984). "A Resource Based View of the Firm," Strategic Management Review 5: 171-180.

Wood, D.J. (1991). “Corporate Social Performance Revisited,” Academy of Management Review, 16: 691-718. 